\title{
SPATIAL DISTRIBUTION AND INTERACTION OF FOUR SPECIES OF THE CATFISH GENUS Hypostomus Lacépède WITH BOTTOM OF RIO SÃO FRANCISCO, CANINDÉ DO SÃO FRANCISCO, SERGIPE, BRAZIL (PISCES, LORICARIIDAE, HYPOSTOMINAE)
}

\author{
GARAVELLO, J. C. ${ }^{1}$ and GARAVELLO, J. P. ${ }^{2}$ \\ ${ }^{1}$ Departamento de Ecologia e Biologia Evolutiva da Universidade Federal de São Carlos, UFSCar, \\ Rod. Washington Luís, km 235, C.P. 676, CEP 13565-905, São Carlos, SP, Brazil \\ ${ }^{2}$ Programa de Pós-graduação em Ecologia e Recursos Naturais, Universidade Federal de São Carlos, PPG-ERN, \\ UFSCar, Rod. Washington Luís, km 235, C.P. 676, CEP 13565-905, São Carlos, SP, Brazil \\ Correspondence to: Julio Cesar Garavello, Departamento de Ecologia e Biologia Evolutiva da Universidade Federal \\ de São Carlos, UFSCar, Rod. Washington Luís, km 235, C.P. 676, CEP 13565-905, São Carlos, \\ SP, Brazil, e-mail: garavelo@ power.ufscar.br \\ Received September 17, 2002 - Accepted September 12, 2003 - Distributed August 31, 2004
}

(With 5 figures)

\begin{abstract}
The large catfishes, genus Hypostomus Lacépède, are common species in almost all freshwater environments of South America. The behavior of specimens from the species Hypostomus alatus, Hypostomus francisci, Hypostomus cf. wuchereri, and Hypostomus sp., from the region downstream from the Xingó Hydroelectric Power Dam, located in Canindé do São Francisco on the Rio São Francisco, were observed. Morphological characters collected from preserved specimens were also studied in the laboratory, in order to shed light on interactions between those fishes and the river bottom. In addition, the formulation of Gatz (1979) was applied to better explain the environmental interactions of Hypostomus species. This study revealed that the fishes utilize their suckers, through a mouth equipped with an oral disk, as well as the pectoral, pelvic, and caudal fins areas, to interact with the rocky river-bottom. The comb-toothed inferior mouth of the Hypostomus showed itself able to grasp green algae on the river bottom. With the help of the oral disk and sucker mouth, which anchor the fishes, in conjunction with the arched design of pectoral and pelvic fin spines, they are also able to remain upright while exploring this substratum. In addition, their large, concave caudal-fin is associated with fast locomotion over short distances. This combination of characteristics allow these fish to live on the bottom of large South American rivers.
\end{abstract}

Key words: catfishes, Rio São Francisco, Hypostomus, Loricariidae, ecological interactions.

\section{RESUMO}

\section{Distribuição espacial e interações de quatro espécies do gênero Hypostomus Lacépède com o fundo do Rio São Francisco em Canindé do São Francisco, Sergipe, Brasil} (Pisces, Loricariidae, Hypostominae)

Os "cascudos" do gênero Hypostomus são comuns em todos os ambientes de água doce da América do Sul. O comportamento de peixes pertencentes a quatro espécies desse gênero, Hypostomus alatus, Hypostomus francisci, Hypostomus cf. wuchereri e Hypostomus sp., foi observado. A morfologia externa também foi estudada em espécimes preservados em coleção procedentes da localidade de Canindé do São Francisco, em regiões a jusante da usina hidroelétrica de Xingó, Estado de Sergipe. Foram estudados caracteres anatômicos e o protocolo de equações descritas por Gatz (1979) foi utilizado para explicar algumas das interações dos peixes com o ambiente bentônico do rio. Os resultados revelaram que os peixes se utilizam da região bucal através do disco oral que produz forte ação suctória 
e das nadadeiras pares para se equilibrarem no fundo rochoso do rio São Francisco. Descreve-se ainda a ação dos espinhos das nadadeiras peitorais e pélvicas em arco, que permitem aos peixes se ancorarem horizontalmente sobre o fundo do rio. A nadadeira caudal tem formato entalhado, promovendo locomoção rápida na coluna de água. É ainda discutida a ação dos dentes móveis e em forma de pente, que atuam na raspagem de algas que crescem sobre as rochas do fundo. A atuação desses caracteres de maneira associada sugere que as espécies do gênero Hypostomus devem habitar e interagir com o ambiente bentônico dos rios maiores da América do Sul.

Palavras-chave: peixes, rio São Francisco, Hypostomus, Loricariidae, interações ecológicas.

\section{INTRODUCTION}

The large catfish species of genus Hypostomus Lacépède are known for living in clear running water on the rocky bottoms of mostly large South American rivers. In spite of their large distribution throughout Brazilian rivers, very few studies are available on their ecological interactions with these fast freshwater river environments as well as on the morphological characters utilized by these fishes in exploring them.

The ranking of species of Hypostomus from the Rio São Francisco basin includes those originally described by: Castelnau (1855): Hypostomus alatus and Hypostomus subcarinatus, Lütken (1875): Hypostomus francisci and Hypostomus lima $=$ Hypostomus wuchereri Günther, Eigenmann and Eigenmann (1888): Hypostomus macrops, and Regan (1904): Hypostomus garmani. Britski, Sato \& Rosa (1988) listed the Hypostomus species from the Rio São Francisco in the Três Marias region, Minas Gerais, as follows: Hypostomus francisci, Hypostomus cf. margaritifer, and a species referred to as Hypostomus sp. 1. Collections and observations on specimens of this genus from the region of Canindé do São Francisco, downstream from the Xingó Hydroelectric Power Dam, have been made on the species Hypostomus alatus, Hypostomus cf. wuchereri (= Hypostomus lima), Hypostomus francisci, and Hypostomus sp.

The ability of these catfishes to survive in diverse Neotropical river environments was called attention to by Lowe McConnell (1963). She identified Hypostomus plecostomus, Hypostomus hemiurus, and Hypostomus emarginatus as common species dwelling in small tributary environments, having sandy and/or rocky bottoms, in the hydrographic basin of the Rupununi River, British Guyana. This author also cited the species Lithoxus lithoides as an example of a primary species apt for survival in torrential environments and, with its depressed body anatomy, dwelling over river-bottom rocks and cobblestones.

Alexander (1970) discussed the utilization of mouth and lip movements by Hypostomus sp. in maintaining stability vertically on aquatic substrata. $\mathrm{He}$ also described the effect of labial sucker movement, which was judged to be independent of the grasp of the dental teeth which interact with bottom surfaces, gripping algae growing along and over aquarium walls.

Gosline (1971) described the behavior of Loricariidae catfishes in swimming to the water surface to get an air-bubble, which is then pushed to the digestive system where these fish have accessory breathing organs.

Schaefer \& Lauder (1986) described the specialized anatomic modifications acquired by the oral system of the Loricariidae, focusing on the Hypostomus species. According to these authors, the oral modifications developed by this fish during evolution, include the ability to combine mouth suction with the mobile dentition needed to grasp and to explore benthic substrata. The studies of Power et al. (1989), and Power (1990), who reported on the distribution and feeding behavior of several species of loricariid fishes, identified Hypostomus plecostomus from the Río Frijoles in Panamá, describing these catfish as primary consumers, grazing on vegetal bottom covering and algae colonies.

Schaefer \& Stewart (1993), who studied feeding habits of Panaque dentex species, determined that these fishes can grasp wood substratum, getting organic matter with the help of spoon-like teeth. Buck \& Sazima (1995) studied four species of Loricariidae catfishes from the Riacho da Serra, São Paulo, including distribution, activity 
spectrum, and diet of the genera Kronichthys, Harttia, Schizolechis, and Ancistrus. They also registered a species of the genus Hypostomus living near the studied area.

Garavello \& Santana (1998) described the strategy utilized by catfishes of the genus Pareiorhina, also a member of Loricariidae family, to maintain equilibrium in environments characterized by running water, waterfalls, and rocky or sandy bottoms.

Utilizing the anatomic discussions of Schaefer $\&$ Lauder (1986) on the Hypostomus species, the experience of Power (1990) with Hypostomus plecostomus from the Río Frijoles in Panamá, and the anatomic formulations of Gatz (1979), this study examined the interactions made possible by some of their morphological characters, between these species and the bottom of the Rio São Francisco. The oral disk area, the large dorsal and pelvic fins, as well as of the caudal fin of four species of this genus were studied, so as to better explain the interactions of those features with the bottom environment of the Rio São Francisco.

\section{MATERIAL AND METHODS}

This research includes observations previously made in studies of behavior and morphological characters of a large number of specimens of Hypostomus alatus, Hypostomus cf. wuchereri, Hypostomus francisci, and Hypostomus sp. from the benthic environment of downstream waters of the Xingó Hydroelectric Dam, Rio São Francisco ( $\left(9^{\circ} 65^{\prime} \mathrm{S} /\right.$ $\left.38^{\circ} 12^{\prime} \mathrm{W}\right)$. The totality of observed and collected specimens were from places influenced by torrential waters, as seen in Fig. 1. Large preserved specimens from museum collections were also studied in the laboratory in order to obtain measurements of morphological features of catfishes. We also studied Hypostomus specimens from the following institutions: Laboratório de Ictiologia Sistemática do Departamento de Ecologia e Biologia Evolutiva of the Universidade Federal de São Carlos (LISDEBE-UFSCar); Museu de Zoologia of the Universidade de São Paulo (MZUSP); and the Núcleo de Pesquisas em Limnologia, Ictiologia e Aqüicultura of the Universidade Estadual de Maringá (NUPELIA). The presently confusing taxonomy of genus Hypostomus, allied with morphological similarities in this species, required a previous taxonomic study of those found at least until recently in the Rio São Francisco main channel.
The morphological characters here discussed were observed under Olympus binocular stereomicroscope. Photographs were taken with a Pentax Asahi. Local observations were done macroscopically and/or using aquatic masks. Fish dissection was done under the stereomicroscope in the laboratory. All material studied was fixed with $10 \%$ formalin and preserved in $70 \%$ alcohol solution, and was subsequently deposited in the fish collection of LISDEBEUFSCar.

Measurements and comparisons utilized followed the protocol of Gatz (1979) adapted to the genus Hypostomus. Selected morphological characters were studied by mean of ratios for each species, and the data were evaluated with the Microsoft Excel Program. Statistical correlations between estimated pectoral and pelvic fin areas versus estimated body area, estimated caudal fin area versus estimated body area, and estimated oral disk area versus estimated body area were obtained to form a basis for discussing their interactions with the bottom environment.

Measurements were obtained with Vernier calipers to the nearest millimeter, following Garavello (1977): A. standard length (length from tip of snout to base of caudal fin rays); B. body depth (depth at vertical with dorsal-fin origin); C. body width (widest region of scapular bridge), with addition of the following characters; D. oral disk width (horizontal width of the oral disk); E. oral disk length (vertical depth of oral disk); F. pectoral fin length (length from tip to base of the pectoral spine); G. pelvic fin length (length from tip to base of the pelvic spine); $\mathrm{H}$. pectoral fin width (width from tip of extended to last branched pectoral ray); I. pelvic fin width (width from tip of extended to last branched pelvic ray); J. caudal fin length (length from upper tip to lower tip of extended caudal fin rays); K. caudal fin depth (depth from base to tip of intermediate branched caudal fin rays), and submitted to the following equations: Equation 1 = F.H/A.C; Equation 2 = G.I/A.C; Equation $3=$ J.K/A.B; Equation $4=$ E.D/A.C.

\section{DISCUSSION}

In the torrential environments of the Rio São Francisco, the Hypostomus species are widely distributed downstream from the Xingó Hydroelectric Power Dam. According to data obtained by this study as well as some previous ones, the Hypostomus 
seems to readily withstand environmental changes produced by hydroelectric projects. They may even benefit by changes downstream from the dams, which bring clean and decanted water from the reservoirs, resulting in more illuminated environments above their rocky bottoms. Here, algae and periphytic vegetation grow continuously, enabling the fishes, using their large oral disk area as well as their large pectoral, pelvic, and caudal fins areas, to interact with the river bottom.

Gosline (1947), who studied the anatomic specialization of the sucker mouth and pectoral and pelvic fins of Hypostominae, particularly the genus Hypostomus, recognized their ability to dwell on the bottoms and in the running waters of large South American rivers. Schaefer \& Stewart (1993), studying the loricariid catfishes genus Panaque, distinguished the large-sized species Panaque nigrolineatus in Amazonian rivers (a species very similar in size to the São Francisco Hypostomus), and considered them as resident species in large rivers. On the other hand, these authors did not find the Panaque species in cold environments of streams and creeks at altitudes of over 300 or $400 \mathrm{~m}$ in Venezuela. Thus, the Panaque nigrolineatus, as well as the large Hypostomus species, studied here in a similar manner, may be especially equipped for surviving in the large South American rivers.

Power (1990) and Antoniassi et al. (1998) also observed the environmental preferences of Hypostomus species for clean and running waters of the large Brazilian rivers. Both authors agree that this species not only withstands barrage events but may also benefit by the luminous environments below the dam. In addition, decanted water from the reservoirs results in an aquatic environment favoring the development of plentiful algae and banks of periphytic vegetation. Our observations revealed that the four species of Hypostomus from the Xingó region preferred to feed, with the help of their comb-teeth and oral disk, while swimming near the bottom. Continuous assemblages of Hypostomus species were observed grasping at the rich banks of algae vegetation on the river bottom. Power et al. (1989) also describe this behavior for Hypostomus plecostomus from the Río Frijoles, Panamá, and Antoniassi et al. (1998) do the same for other species of this genus in the Rio Paraná basin. This fact allows the classification of the Hypostomus species as iliophagous.
Individuals of both species from the Rio São Francisco continuously move over cobblestones on bottom environments, alternating between feeding and emerging to the water surface to catch a gas bubble with the help of their mouth. No preference for bottom-stone type was found, and individuals explore the whole bottom area by grasping at the stones' surface while maintaining their balance with the help of the flesh oral disk and the action of the arched, undivided branch of each pectoral as well as of the pelvic fins. These arched fins allow the fish to maintain their balance against the current. Fast swimming movements were produced by the action of their large caudal fin and the thick muscular caudal peduncle, which propels the fish. As related by Gosline (1971) and verified by Power (1990) for Hypostomus, the large caudal fin area of catfishes favors the fast aquatic locomotion over short distances. Our observations suggest that, if associated, the action of the oral disk, pectoral and pelvic spines, and strong quadrangular caudal peduncle aids fish equilibrium on the bottom. These special features and morphologic associations are spread throughout the family, with the exception of the Loricariinae fishes.

A morphometric analysis according to Gatz (1979) was applied to characters from the species of genus Hypostomus resulting in the ecological ratios between characters (Table 1) which constitute the basis of the discussion on interaction with the bottom substratum, as seen ahead.

Ratios between the pectoral fin length and pectoral fin width versus standard length and body width with values near 0.24 could be considered elevated ratios for each studied species. These may reflect, in accordance with Gatz (1979), the relatively large pectoral fin area strongly associated with benthic habits. In the same way, Lundberg \& Marsh (1976) reported on how the fish suckers of the family Catostomidae are able to explore bottom substrate, using their pectoral fins and large sucker mouth, comparisons between which also show high ratios. According to these authors, these ratios in fishes with compressed bodies have near-zero values. Also, comparisons between the pelvic fin length and pelvic fin width versus standard length and body width resulted in ratios of 0.15 to 0.17 for each species. Ratios from compressed bodies (values near zero) may be considered elevated, reflecting the fact that a large pelvic fin area may be an attribute suiting the species for living in rocky-bottom habitats. 


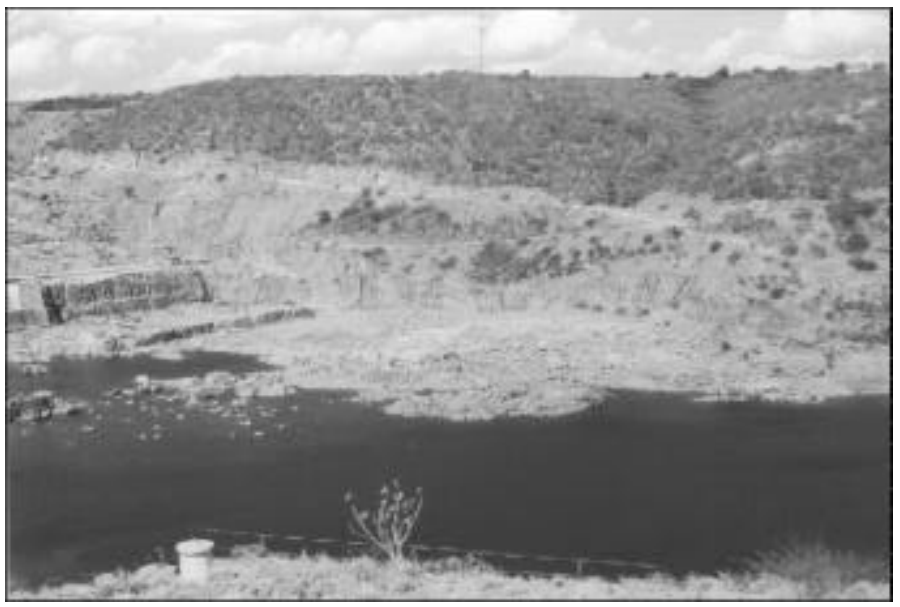

Fig. 1 - Rio São Francisco downstream from Xingó hydroeletric power dam.

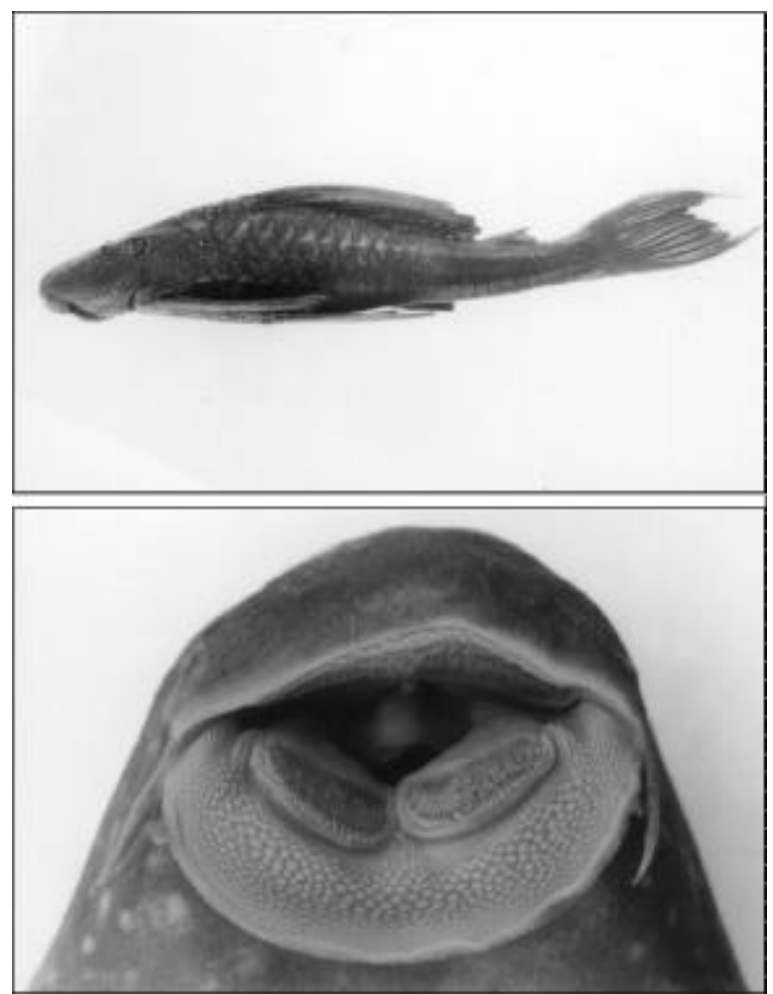

Fig. 2 - Lateral and ventral mouth view of Hypostomus alatus. 
TABLE 1

Results of four equations on the measurements of the Hypostomus species.

\begin{tabular}{|l|c|c|c|c|c|c|c|c|c|}
\hline \multirow{2}{*}{\multicolumn{1}{|c}{ Species }} & \multirow{2}{*}{$\mathbf{N}$} & \multicolumn{2}{c|}{ FH/AC } & \multicolumn{2}{c|}{ GI/AC } & \multicolumn{2}{c|}{ JK/AB } & \multicolumn{2}{c|}{ ED/AC } \\
\cline { 3 - 10 } & & Mean & S.D. & Mean & S.D. & Mean & S.D. & Mean & S.D. \\
\hline H. francisci & 23 & 0.24 & 0.32 & 0.17 & 0.25 & 0.11 & 0.017 & 0.29 & 0.042 \\
\hline H. alatus & 04 & 0.24 & 0.25 & 0.16 & 0.25 & 0.10 & 0.007 & 0.25 & 0.070 \\
\hline H. cf. wuchereri & 15 & 0.24 & 0.22 & 0.15 & 0.16 & 0.12 & 0.014 & 0.29 & 0.087 \\
\hline Hypostomus sp. & 03 & 0.23 & 0.22 & 0.16 & 0.30 & 0.09 & 0.008 & 0.26 & 0.046 \\
\hline
\end{tabular}

$\mathrm{N}=$ number of individuals; Mean $=$ simple mean of ratios; $\mathrm{SD}=$ standard deviation.

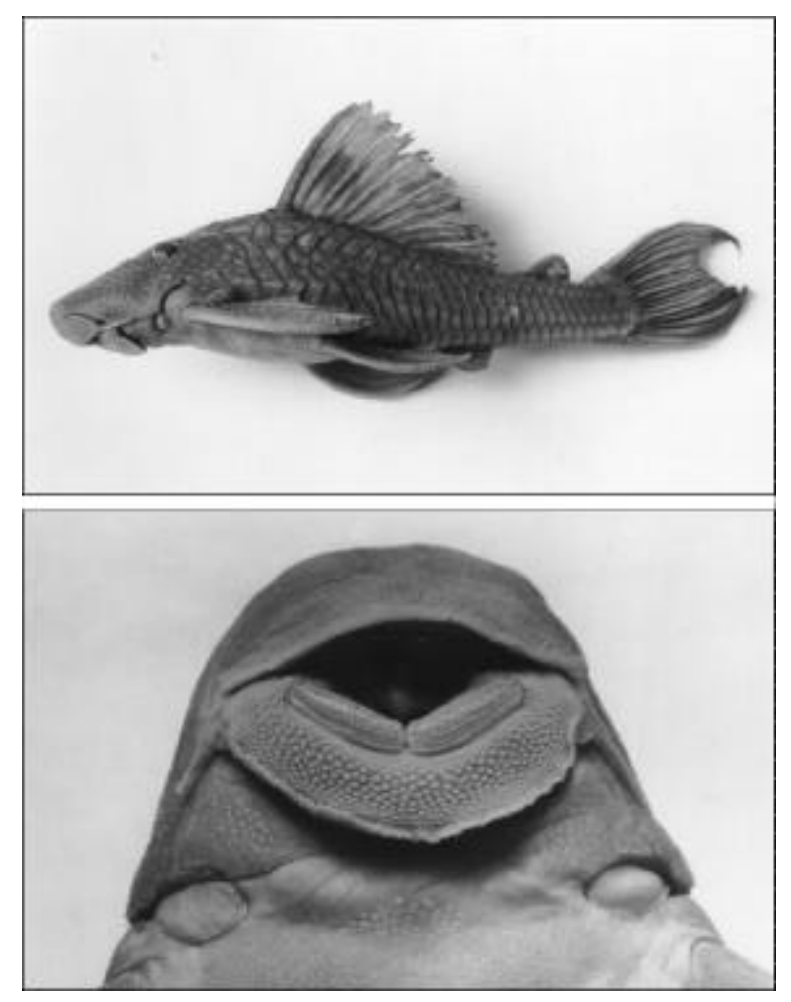

Fig. 3 - Lateral and ventral mouth view of Hypostomus francisci.

The caudal fin length and caudal fin depth were compared to standard length and body depth and, as in Gatz (1979), the caudal span/body depth ratio was directly proportional to the amount of swimming done by the fish. Looking at the ratios of 0.09 to 0.11 obtained for each species, they may represent a favorable caudal fin hydrodynamic, an important attribute in rapid change of position on rocky bottoms.

Finally, the oral disk width and oral disk length in relation to the estimated oral disk area, was compared to standard length and body width, again resulting in ratios between 0.25 to 0.29 , which may also be considered elevated for each species. Besides the inferior mouth indicating a species that feeds along river bottoms, the elevated values of ratios between these two comparisons, gives significant weight to the importance of the oral disk in forming the sucker mouth of this fish. This finding may represent the operational integration of sucker mouth and rocky bottom in maintaining fish equilibrium in the previously described environments. 


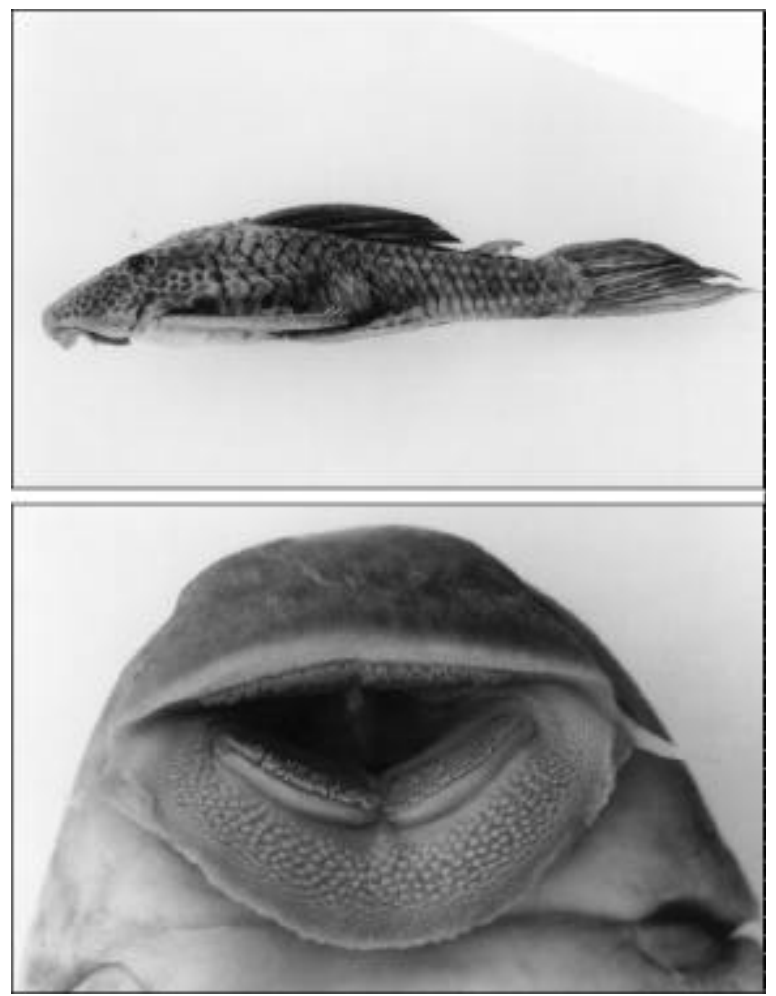

Fig. 4 - Lateral and ventral mouth view of Hypostomus cf. wuchereri.

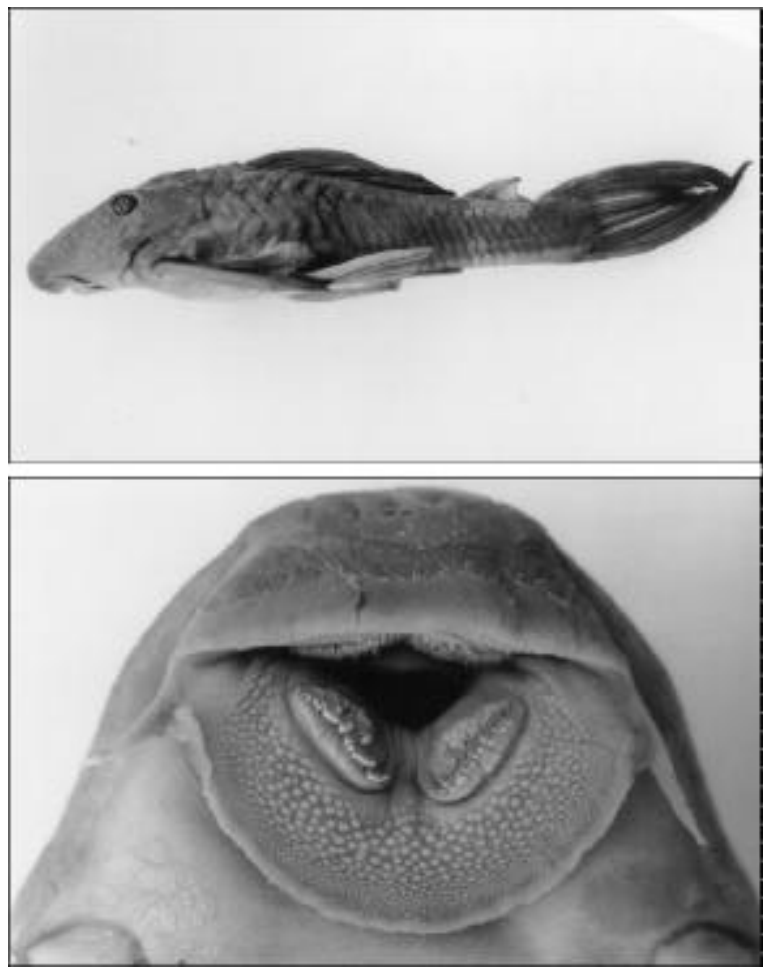

Fig. 5 - Lateral and ventral mouth view of Hypostomus sp. 
In conclusion, the association of the large flesh oral disk with comb-teeth in both jaws, the strong and convex pectoral and pelvic first spine, the caudal fin spines which are concave on both sides, together with the thick quadrangular caudal peduncle may enable the Hypostomus species from Canindé do São Francisco to explore the bottom environment of the Rio São Francisco and may be doing the same for the remaining species of this genus.

Acknowledgements - We are grateful to the Conselho Nacional de Desenvolvimento Científico e Tecnológico (CNPq), which through the Graduate Program in Ecology and Natural Resources of the Universidade Federal de São Carlos supported the junior author with a MSC grant. The first author was also supported by a research grant from $\mathrm{CNPq}$ and both authors had field and laboratory support funded by PRONEX I CNPq Program. Odete Rocha, Angélica P. Dias, from DEBE-UFSCar, and an anonymous reviewer read the manuscript and made suggestions. Heraldo A. Britski from MZUSP helped us in identifying São Francisco species of Hypostomus. José L. de Figueiredo of MZUSP, Carla S. Pavanelli of NUPELIA, and Yoshimi Sato of the Companhia de Desenvolvimento do Vale do São Francisco (CODEVASF) loaned ichthyological material. We are thankful to each of them. For field support and other facilities we would like to thank Y. Sato and the team of collectors from CODEVASF. Special thanks to Augusto S. Abe of the Universidade Estadual Paulista (UNESP, Rio Claro), who assisted us in collecting specimens and taking photographs in the field.

\section{REFERENCES}

ALEXANDER, R. M. C. N., 1970, Functional design in fishes. Hutchinson University Press, Biological Sciences, London, $160 \mathrm{p}$.

ANTONiASSi, L. E., AGOSTINHO, A. A., GOMES, L. C. \& HAHN, N. S., 1998, Ecologia trófica de peixes em dois riachos da bacia do Rio Paraná. Rev. Bras. Biol., 58(2): 273285.

BRITSKI, H. A., SATO, Y. \& ROSA, A. B. S., 1988, Manual de identificação de peixes da região de Três Marias, São Francisco. Codevasf, Brasília, 115p.

BUCK, S. \& SAZIMA, I., 1995, An assemblage of mailed cafishes (Loricariidae) in southeastern Brazil: distribution, activity and feeding. Ichthyol. Explor. Freshwaters, 6: 325-332.

CASTELNAU, F., 1855, Animaux nouveaux ou rares recueillis pendant l'expedition dans les parties centrales de l'Amerique du Sud, de Rio de Janeiro a Lima et de Lima au Pará 2. Poissons, introd. I-XII; 1-112, 50 pls.
EIGENMANN, C. H. \& EIGENMANN, R. S., 1888, Preliminary Notes on South American Nematognathi I. Proc. Calif. Acad. Sci., I(2): 119-172.

GARAVELLO, J. C., 1977, Systematic and geographical distribution of the genus Parotocinclus Eigenmann \& Eigenmann, 1889 (Ostariophysi, Loricariidae). Arq. Zool., São Paulo, 28: 1-37.

GARAVEllO, J. C. \& SANTANA, I. C., 1998, Functional morphology, ecology and geographic distribution of the neotropical catfish genus Pareiorhina Gosline 1947, from southeastern Brazilian rivers (Pisces, Loricariidae, Hypostominae). Verh. Internat. Verein. Limnol. Stuttgart, 26: $2240-2243$.

GATZ, A. J., JR., 1979, Ecological morphology of freshwater stream fishes. Tulane Stud. Zool. Bot., 21: 91-124.

GOSLINE, W. A., 1947, Contributions to the classification of the Loricariid catfishes. Arq. Mus. Nac. Rio de Janeiro. Zoologia, 33: 1-138.

GOSLINE, W. A., 1971, Functional morphology and classification of teleostean fishes. The University Press of Hawaii, Honolulu, IX + 208p.

LOWE McCONNELL, R. H., 1963, The fishes of the Rupunun savanna district of British Guiana, South America. Part 1. Ecological groupings of fish species and effects of the seasonal cycle of the fish. J. Linn. Soc. Ser. Zool., 45(304): 103-144, 4 text-figs.

LUNDBERG, J. G. \& MARSH, E., 1976, Evolution and functional anatomy of the pectoral fin rays in cyprinoid fishes, with emphasis on the suckers (Family, Catostomidae). Amer Midl. Nat., 96: 332-349.

LÜTKEN, C. H. F., 1875, Velhas Flodens Fiske. Danske. Vidensk Selsk. Skrifter., 12: 122-254.

POWER, M. E., 1990, Resource enhancement by indirect effects of grazers: armored catfish, algae and sediment. Ecology, 7: 897-904.

POWER, M. E., DUDLEY, T. L. \& COOPER, S. D., 1989, Grazing catfish, fishing birds, and attached algae in a Panamanian stream. Envir. Biol. Fish., 26: 285-294.

REGAN, C. T., 1904, A monograph of the fishes of the family Loricariidae. Trans. Zool. Soc., London, 17(3): 191-350.

SCHAEFER, S. A. \& LAUDER, G., 1986, Historical transformation of functional design: evolutionary morphology of feeding mechanisms in loricarioid catfishes. Syst. Zool., 35: 489-508.

SCHAEFER, S. A. \& STEWART, D. J., 1993, Systematics of Panaque dentex species group (Siluriformes, Loricariidae) wood-eating armored catfishes from tropical South America. Ichthyol. Explor. Freshwaters, 4: 309-342. 